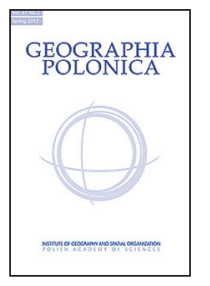

\title{
BORDER POLITICS IN CENTRAL EUROPE: HUNGARY AND THE ROLE OF NATIONAL SCALE AND NATION-BUILDING
}

\author{
James Wesley Scott \\ Karelian Institute \\ University of Eastern Finland \\ Yliopistokatu 2, Fl-80100 Joensuu: Finland \\ e-mail: james.scott@uef.fi \\ Department of Economic Geography \\ University of Gdańsk \\ Bażyńskiego 4, 80-309 Gdańsk: Poland
}

\begin{abstract}
This essay focuses attention on aspects of border politics that give evidence of nation-building and national consolidation processes in Central Europe. In a normative, policy-oriented sense this is a question of borders as framing conditions for regional development. In a more critical and analytical sense this involves interrogating the actual use of borders in politically and ideologically framing national interests within a wider European context. The essay begins with a brief discussion of Europeanisation processes understood in terms of the promotion of cross-border cooperation (CBC) in Central Europe. Here, the significance of national structural conditions for implementation of Cohesion and regional policies and hence $\mathrm{CBC}$ will be discussed. One result that emerges is that while EU-European principles of cross-border cooperation have been partly mainstreamed into regional development policies they have at the same time been superimposed by the domestication of EU policies in the interest of nation-building. More specific evidence is then provided by Hungarian experience where national scale and nation-building have played key roles in conditioning the quality of cross-border cooperation and in the framing of state borders as resources. Attention will focus on: (1) Hungarian exploitation of CBC in the service of ethnopolitical development objectives and (2) Hungary's recent policy of border securitisation which essentially entails a re-nationalisation of its border regime and a framing of the physical border as a protective barrier against threats to national and European identity.
\end{abstract}

\section{Key words}

Central Europe $\bullet$ Hungary $\bullet$ borders $\bullet$ border politics $\bullet$ national scale $\bullet$ cross-border cooperation 


\section{Introduction}

Commenting on the 'misery' of small states within post-war Central and Eastern Europe, Hungarian political theorist István Bibó (1946) drew clear parallels between frustrated projects of nation-building and the difficulty of defining 'good' borders. From Bibó's perspective, the West European experience of forging political borders around political nations appeared distant from Central and Eastern European reality - a reality in which psychological and linguistic frontiers retained central importance. After more than 70 years since the end of WWII, and several territorial reorganisations of Central and Eastern Europe states, European integration and cross-border networks have provided a new historical context for improved relations and more relaxed attitudes towards ideas of nation and 'stateness'. Perhaps for this reason, research interest in Central European cross-border cooperation (CBC) has been sustained for close to three decades and shows no signs of diminishing.

The normative European context, that provided by European Union membership and the EU's political objectives, is an intriguing point of departure. Political exigencies of integration and enlargement as well as basic principles of European Union policy, structural policy in particular, have decisively influenced the development of transboundary co-operation within Europe as a whole. For example, in preparation for EU membership, Central European states have collaborated with the EU in promoting a 'de-bordering' strategy based on financial incentives, the development of local and regional institutions across borders and project-based cooperation. These policies have also been aimed at integrating previously divided border regions in order to build a more cohesive European space.

Research on Central European CBC has followed wider European trends, particularly in two areas: (1) policy-focused approaches that analyse cooperation processes in order to test assumptions of mutual benefit and potential synergies (see Bufon \& Markelj 2010; Domaniewski \& Studińska 2016; Hakser 2017) and (2) interpretations of $\mathrm{CBC}$ as a processes of state re-scaling, region-building and integration at flexible territorial scales (see Lados 2005; Jańczak 2013; Medve-Bálint \& Svensson 2013). Such analyses provide highly useful insights into experimental forms of regional development by applying structural-critical and policy-focused approaches regarding the potentials of and limits to cooperation at the local and regional levels. These analyses have also attempted to reveal the extent to which socio-political borders, as well as institutional, organisational and material conditions, affect local and regional cooperation within Central Europe. As a result, the local and regional focus has been of great value in understanding the vicissitudes of de- and re-bordering, particularly in conjunction with critical assessments of multilevel governance. Local and regional $\mathrm{CBC}$ has also been indicative of the ways in which borders have, since 1989, become to be understood as essential political resources in the pursuit of various development aims. And yet, perhaps due to the dominance of Western European perspectives, CBC has generally been interpreted in terms of putative governance or re-scaling functions that critical regionalist thinking has assigned to them (see Perkmann 1999, 2007; Blatter 2001; Jessop 2002). As Pickels (2010) has argued, postsocialist transformation can only be partly understood in terms of 'universal projects' of institutional harmonisation and economic integration; in order to understand the 'spirit of post-socialism', specific spatial practices, such as territorial politics, require greater attention. Similarly, Jacobs and Varró (2014) suggest that an exclusive focus on what different forms of territorial politics, such as crossborder cooperation, are supposed to do with regard, for example, to economic, political and social integration, can limit understandings of their concrete political significance.

The question of how open borders, EU integration and targeted initiatives of $\mathrm{CBC}$ have affected national societies of Central Europe is highly complex and has numerous ramifications. In fact, it is only possible to approach this question from specific and highly selective 
vantage points. Given that measurements of cross-border integration are notoriously difficult and inherently lack stability, a focus on concrete political uses of borders and how these have shifted might provide a more accurate - if partial - sense of how borders function as resources. One strategy for understanding the contextual significance of $\mathrm{CBC}$ is to simply take a theoretical step back and interpret more than 25 years' experience in using the tools of local and regional cross-border cooperation as but one example of shifting Central European border politics. At the same time, it is necessary to take into greater account the role of national scale and nation-building in Central (and Eastern) Europe - an aspect that the research state of the art has often ignored. Here, nation-building represents unfinished business, a process that was curtailed by war and its geopolitical aftermath and that now coincides, often uncomfortably, with the simultaneous project of European integration. Following the observations of Nagy and Nagy (2013), Pisciotta (2016) and Varró (2008) regarding territorial politics in general, I suggest that in order to interpret Central European border politics and appropriations of $\mathrm{CBC}$ more substantially, questions relating to the creation of stable conditions for national development and economic transformation need to be taken into consideration. In short, the quest for national consolidation in response to profound political, social and economic change is a major conditioning factor of Central Europe's re-bordering.

This essay will focus attention on aspects of border politics that give evidence of nationbuilding and national consolidation processes within the EU. State borders reflect and thus help us interpret tensions as well as points of connection within intercultural and interstate relations. They can also indicate tensions and contradictions inherent in Europeanisation processes that have taken place since 1989. In a normative, policy-oriented sense this is a question of borders as framing conditions for regional development. In a more critical and analytical sense this involves interrogating the actual use of borders in politically and ideologically framing national interests within a wider European context. The essay begins with a brief discussion of Europeanisation processes understood in terms of the promotion of cross-border cooperation in Central Europe. Here, the significance of national structural conditions for implementation of Cohesion and regional policies and hence $C B C$ will be discussed. One result that emerges is that while EU-European principles of cross-border cooperation have been partly mainstreamed into regional development policies they have at the same time been superimposed by the domestication of EU policies in the interest of nation-building. More specific evidence is then provided by Hungarian experience where national scale and nationbuilding have played key roles in conditioning the quality of cross-border cooperation and in the framing of state borders as resources. Attention will focus on: (1) Hungarian exploitation of $C B C$ in the service of ethnopolitical development objectives and (2) Hungary's recent policy of border securitisation which essentially entails a re-nationalisation of its border regime and a framing of the physical border as a protective barrier against threats to national and European identity. Ironically, we can conclude that the ethnopolitical and securitisation agendas that inform Hungarian border politics have in fact made cooperation much more complex by politicising everyday $\mathrm{CBC}$ and arousing mutual mistrust. Hungary's national development interests would be much better served through dialogue and a productive understanding of cooperation as a trust-building project.

\section{Cross-border cooperation, national scale and border politics}

CBC research - with its close ties to border studies and political geography, has developed a contextually sensitive understanding of the nature of borders, which, at its most basic, involves socio-political processes of 'ordering' that allow for spatial framings of social action (van Houtum \& Naerssen 2002; Newman 2011; Scott 2012). Borders, however, 
also reflect the cultural and symbolic constitution of societies at a more general level and as such play an important role in framing and regulating social relations as well as setting conditions for local and regional development. As a result, borders have been used as explicit symbols of European integration, political community, shared values and, hence, identity by very different actors (Perkmann 2007; Popescu 2008). CBC has thus been related only not to the functions but also the symbolism of state borders as a spatial organisation of difference. The concept and practice of cross-border cooperation (CBC), which began in the 1950s as gestures of reconciliation between Dutch and German communities, have now achieved an important role as vehicles of local-level economic and social development. Since 1989 different forms of territorial cooperation across state borders have become a ubiquitous feature in Central and Eastern Europe. Cooperation forms include Euroregions, cross-border city partnerships, European Groupings for Territorial Cooperation (EGTCs) and other associations (Lepik 2012; Medve-Balint \& Svensson 2013).

With respect to Europe, one important research challenge remains in recognising the different ways in which national and European elements co-exist in the construction of borders within and between different political cultures and how these images continue to shape opinions and attitudes on borders in different European countries. According to O'Dowd (2002), $\mathrm{CBC}$ has developed in Europe as a function of shifting state formations and changing border regimes. O'Dowd has also indicated that as part of integration and enlargement logics, European borders have been being reframed in terms of their (often conflicting) significance as Barriers, Bridges, Resources and Symbols of Identity and how these reconfigurations relate to the project of European integration and enlargement. Furthermore, O'Dowd (2010) has chided border scholars who since 1989 have engaged in 'post-national thinking'. He argues that this indicates a lack of historical reflexivity and careless 'epochal thinking' that ignores the fact that states, state borders and their impacts are very much in evidence in Europe and elsewhere. O 'Dowd has also criticised the use of neologisms such as 'debordering' and 'rebordering' that privilege subjective agency and neglect the structuring power of state borders.

Research on Central European CBC has by no means ignored the conditioning effects of state agency despite its focus on local and regional networks. This is evidenced by a wealth of insightful research into processes of $\mathrm{CBC}$ in Central Europe (Hajdú 1998; Hardi 2003; Lados 2005; Halás 2007; Jańczak 2013; Dołzbłasz 2013, 2015; Sarmiento-Mirwaldt \& Roman-Kamphaus 2013; Hakszer 2017). This research has also investigated the European Union's impact on the nature of cross-border relations in Eastern and Central Europe, suggesting that the normative political language of Europeanisation (e.g. as a process of de-bordering regional development) has in several ways contrasted with realities at CEC borders - a situation where cross-border co-operation has reflected competing territorial logics at the EU, national, regional and, local levels and conflicting attitudes towards more open borders.

However, as a means of developing and complementing existing research, targeted focus on nation-building and state action could provide more explanation regarding rationales behind $C B C$ as well as difficulties in developing cross-border social capital and networks (Svensson 2015). In referencing the insights of the Committee of the Regions, De Sousa (2013) argues that propensities to engage in local and regional $C B C$ are conditioned by: (1) overlapping interests, (2) shared historical memories, (3) strong interdependence due to geographical or economic factors, (4) more general (e.g. national) political projects targeting future joint action. I would argue that considerably more attention should be directed to the last of these factors as major conditions for regional cooperation within Central Europe are set by political and structural contexts that operate at and across national scales.

The conceptualisation of border politics that will be applied here suggests an open-ended 
process of political, economic and social uses of state borders in order to achieve specific goals. While this notion is closely linked to the idea of the border as a resource (see Sohn 2014), the focus will be on the national level. As Paasi argues (2012: 2307), understanding borders is inherently an issue of understanding how states function and thus: "(...) how borders can be exploited to both mobilise and fix territory, security, identities, emotions and memories, and various forms of national socialisation". The continued salience of border politics should therefore not come as a great surprise: the European experiment of transcending nationally-oriented thinking never seriously entertained the elimination of borders as such. What was intended was to make borders less visible, less a part of everyday life and much a less a constraint to interaction. Similarly, Jańczak (2011), Herrschel (2011) and others have suggested that the momentum of European integration has contributed to overlapping processes of border transcendence and confirmation, not least because of deeply rooted historical memories that continue to imbue national borders with highly symbolic meaning.

\section{National development and the tenacity of bordered thinking}

Central Europe has been attributed a crucial role in promoting Cohesion and $\mathrm{CBC}$ within the context of the EU's enlargement process. Given its historic significance, Central Europe's post-1989 de-bordering was a milestone, and indeed a major challenge, in the development of European Union as a political community. The elimination of border defenses and barbed-wire between East and West was, for example, highly symbolic in that it portended a reconstitution of a pan-European space and good neighbourhood relations between individual states. For citizens of Central European countries, and in terms of everyday life, de-bordering was perceived as a new liberty to travel and to express oneself as a 'normal' European. The momentum of European enlargement and process of pre-accession, accompanied by large development subsidies, served to deemphasise the significance of borders as barriers. This was also promoted by the gradual integration of Central Europe into the logic of European Cohesion Policy, which strategically targeted local and regional cross-border cooperation.

As part of Cohesion Policy, CBC is an area where the European Union and advocates of local level cooperation have exerted considerable adaptive pressure in countries such as Hungary, Poland, Slovakia and the Czech Republic. Nevertheless, as Popescu (2006, 2008) has suggested, EU inspired strategies of institutionalised CBC in Central and Eastern Europe - an area of complex social, economic and political diversity - have tended to be 'co-opted' by specific nationally defined interests. In its edition of 20 October 2009, the Hungarian daily 'Népszabadság' openly reflected on this state of affairs, lamenting a lack of true cross-border cooperation with neighbouring states, citing national particularisms and limited European vision. ${ }^{1}$ With the instruments of European regional policy highly centralised both in Hungary and neighbouring states, the article claimed that very little support was offered to local governments for cooperation across state borders. I argue that one of the reasons for this is that, while avid learners of EU norms and governance practices, Central European countries have developed a much more domestically focused interpretation of $\mathrm{CBC}$. In fact, and for understandable reasons, national consolidation has tended to dominate CEC regional development thinking, a fact that has strengthened core area perspectives and central management. This is exacerbated by adherence to understandings of regional development that have not fully adopted the concepts and tools of territorial cooperation, resulting in a focus on large-scale national development projects and infrastructure (Kozak 2014; Scott \& Szalai 2015). In practical terms, CBC

\footnotetext{
1 Reference is to the article "Nem jött létre a 'régiók Európája" (the Europe of Regions has not come about), reporter: István Tanács.
} 
remains as a minimalist exercise - national strategic plans generally take it into consideration as an extension of national development. At the same time, highly symbolic regional cooperation vehicles, such as the Visegrad 4 and the Euroregion Carpathia have proved too weak to actually form a basis for concrete interstate projects and initiatives, networking.

Reasons for the tenacity of bordered thinking have been suggested by Orlowski (2010) who considers the stark consequences of enlargement a major factor; the clear lack of East-West convergence has in fact cemented divisions within Europe as a whole and with Central Europe in particular. This minimalist, instrumental approach of CECs also reflects difficult cooperation contexts which include: lack of local capacity to promote co-operation, cumbersome EU regulations and project management rules, interstate tensions and ethnolinguistic conflict, as well as local orientations to national centres and European core regions rather than to neighbouring states (see, for example, Baranyi 2008; Mezei 2008; Hajdú et. al. 2009; Hárdi 2010). As Hakszer (2017) has indicated, Slovakian-Hungarian cooperation has been highly polarised: most activity has taken place between municipalities located near the capital city regions while peripheries, where demand for development is greatest, have been clearly marginalised. Apart from development goals that privilege dynamic centres, an important reason for this is the political prioritisation of 'HungarianHungarian' relations and thus the targeting of larger settlements with Hungarian minorities on the Slovakian side.

One explanation for the limits to CBC is thus structural, and relates to national level development concerns. After having achieved general de-bordering goals in a functional sense, socio-economic and territorial divisions have diminished impetus for greater social and socio-economic interaction across Central European borders (Jańczak 2013). As several EU Reports on Social and Economic Cohesion document, despite increases in general welfare the imbalances between Europe's core areas and its vast peripheries remain and depopulation of many rural zones continues unabated. ${ }^{2}$ Furthermore, regional disparities as well as cultural and political heterogeneity are certain to increase as a long-term result of enlargement. Gorzelak and Smętkowski (2010) have also shown that, in stark contrast to the objectives of Cohesion Policy, a consolidation and 'petrification' of territorial patterns based on core-periphery inequalities is taking hold in Central European states (Gorzelak \& Smętkowski 2007). This process of growing territorial differentiation is based on relative abilities to, first, attract/generate investment, especially into innovative sectors; and, second, relative proximity of and accesibility to economically dynamic urban centres. In Central Europe, both EU internal and external borders are with a few notable exceptions characterised by pronounced maginalisation, regions at these borders are relatively underdeveloped in both quantitative and qualitative dimensions and continue to lose highly qualified workers to metropolitan cores. As a result, domestic polarisation reinforces structural conditions of West-East dependence, and this, in addition to ethno-political tensions, has tended to fragment the region and thus limit the overall impact of cross-border cooperation.

Finally, it should be mentioned that shifts in European Union priorities and approaches in programming Cohesion and Territorial Cooperation Policy have also played an important role in conditioning Hungary's 'domestication' of European Union policies. There is in fact little doubt that since the historic turn of events of 1989/1991, and the heady days of a creating a new European order, there has been a shift in the EU's focus on CBC. Most

\footnotetext{
2 European Commission (2014) Investment for Growth and Jobs. Promoting Development and Good Governance in EU Cities and Regions. Sixth Report on Social, Economic and Territorial Cohesion, Brussels: European Commission; European Communities (2007) Growing Regions, Growing Europe. Fourth Report on Economic and Social Cohesion. Luxembourg: Office for Official Publications of the European Communities; (2004) A New Partnership for Cohesion, Convergence, Competitiveness, Cooperation. Third Report on Economic and Social Cohesion. Luxembourg: Office for Official Publications of the European Communities.
} 
recently, $\mathrm{CBC}$ has been subsumed within the more inclusive notion of Territorial Cooperation (TC) and its main aim remains to reduce the negative effects of borders as administrative, legal and physical barriers, tackle common problems and exploit untapped potential. It is clear from recent debate on European Cohesion that the EU stakes much of its political capital on more traditional instruments of redistribution that are nationally oriented even if subject to supranational guidelines. Indeed, the 2007-2013 budget of $€ 8.7$ billion for Territorial Cooperation amounted to a mere $2.5 \%$ of the total Cohesion Policy budget. Furthermore, a major overall share of Cohesion funds are targeted to Central and Eastern European countries where there appears to be less enthusiasm for $\mathrm{CBC}$ as a regional development resource.

\section{The case of Hungary: Cooperation, ethnopolitics and securitisation}

Hungary offers perhaps the greatest degree of contrast in terms of shifting Central European border politics. It is, in many ways, a singular case, given the specific historical experience of Hungary as a sovereign nationstate. However, the marked transformation in Hungary's border politics indicate many of the tensions between national and community interests that have emerged as part of European enlargement and integration. For historical and geographical reasons, Hungary can be understood to be a laboratory of Europeanisation, both in terms of the local adaptation of EU norms and practices (Ágh 2003), progressive legislation regarding minority rights (Vizi 2009) and practices of cross-border co-operation (Baranyi 2008, Hardi 2010) As will be discussed in the following, Hungarian border politics have been characterised by change and continuity, reflecting different strategic orientations and shifting nation-building priorities as they have been influenced by European integration. The actors involved in these processes are many; while political elites are the most visible, academics and popular media are also important architects of border politics. In the following, three interlinked aspects of Hungarian border politics will be elaborated that give evidence of the significance of national borders and nation-building. These are: the use of borders for regional development purposes, ethnopolitical concerns and national security.

\section{CBC as Regional Policy}

Initial openness to EU notions of de-bordering and regional cooperation was at its apogee and within the post-1989 context of European integration Hungarian borders were conceptualised as regional development contexts in close alignment with a wider European reading of Cohesion Policy (see Barta 2006). For example, in the case of Hungary, 'post-socialist' regional studies since the first studies of Rechnitzer (1990) very much focused on the development of new local economic networks between Hungary and its neighbours and the roles that border regions play in their creation. As development trends in the early 1990s indicated, post-socialist economic transformation and differential border effects contributed to the exacerbation of core-periphery relationships. Distinctions were made in terms of characterising Hungary's borders between successful and dynamic Western border areas (those with Austria and Slovakia) and declining eastern border regions neighbouring Romania, Eastern Slovakia and Ukraine (Baranyi 2001; Kukorelli et. al. 2000; Bihari \& Kovács 2005). Similar to the regional development context, specific Hungarian borders were also conceptualised within a wider European context of economic integration and Cohesion. The Concept of Border as National Periphery was perhaps most vigorously expressed by Baranyi (2001) who depicted Hungary's eastern border regions as 'peripheries of the periphery'. Baranyi developed a number of arguments in which border areas and settlements were clearly identified as regional development problems where cross-border co-operation held out prospects of linking in to more general EU development processes. 
It the reading, the perspective of overall national perspective of balanced development was related to the re-establishment of urban networks in the Carpathian Basin - a largely Hungarian reference to the geographical area encompassed by the Carpathian Mountains and which historically formed the borders of the Kingdom of Hungary. However, in this regional development reading, emphasis was squarely placed on cooperation and the reestablishment of the functional relationships between mid-size cities and different core areas of the region (Süli-Zakar \& Czimre 2001; Süli-Zakar 2002; Horváth 2010). Within this context, a major narrative was that of crossborder cooperation as a positive value and political strategy more in tune with the realities of an integration Europe and thus a clear alternative to the fruitless irredentism of the past (Eger 2000).

During the period between 1996 and roughly 2010, the Hungarian government demonstrated considerable commitment to facilitating $\mathrm{CBC}$ through the inclusion of regional and local actors (Soós \& Fejes 2007). In addition, there was a clear emphasis on regional development and spatial cohesion as a part of national strategy, even though the welfare of Hungarian minorities certainly remained an important political goal (Rechnitzer 2001). Government support of CBC was informed by the wider European goal of territorial cohesion and the desire for greater functional interrelationships within the Carpathian Basin gradually materialised as evidenced by crossborder labour markets and shopping patterns indicate (Mezei 2008; Horváth 2010). Nagy (2011) also states that the cross-border centrality of Hungarian cities such as Gyula, located at the Romanian border, is not a mere function of ethnic relations but involves Hungarian - ethnic Romanian interaction as well. Nevertheless, the Hungarian government's direct support of local and regional forms of $\mathrm{CBC}$ declined after EU membership. And indeed in the case of Hungarian national development strategies of 1998 and 2007 a marked change can be noted. While in the first document Hungarian border areas and regional development issues related to cooperation with neighbouring states received generous coverage, the 2007 National Development Strategy (National Development Agency 2007) only gives very brief mention of CBC.

Since 2010 the issue of subnational participation in $\mathrm{CBC}$ has become much more uncertain. Having eliminated the seven regions that were involved in programming EU funds, the present (2017) government has sought to increase the role and visibility of the central government in managing territorial organisation and socio-economic development in the Carpathian Basin (see Pálmai 2013). CBC provided and still provides an important level of trust-building across borders but the lack of strong local and/or other subnational governments limits the actual ability of these actors to engage in development projects across borders. Indeed, the only true working $\mathrm{CBC}$ institutions are in the West, on the border with Austria as well as the Istergránum EGTC between Hungary and Slovakia (Esztergom-Komárom-Komarno). Most Euroregions appear to have outlived their functions as regional mediators - made redundant by a combination of institutional flux (recentralisation), a lack of institutional support, and political uncertainty in Central Europe (see MedveBálint 2013). It is remarkable, for example, that Gábor Nagy (2011) in his study of crossborder urban networks makes almost no mention of Euroregions and institutionalised forms of CBC. Instead, he focuses on functional networks and relationships as drivers of crossborder interaction between Hungarian and Romanian towns. In practical terms, CBC remains as a minimalist exercise - national strategic plans generally take it into consideration as an extension of national development.

\section{Border ethnopolitics}

One of the defining elements of Hungarian nation-building is the political objective of improving connections between Hungary proper and Hungarian communities in neighbouring states. Having championed a 'spritualisation' of borders, and thus the 
transcendence of their historical divisiveness already before the end of the Cold War (see Boldizsar 1988), the country has advocated greater political and cultural opening but also a politics of outreach to Hungarian ethnic communities in neighbouring countries. The situation of Hungarian-speaking communities in neighbouring countries, specifically the large Hungarian populations suffering discrimination at the hands of the Ceaucescu regime, revived political debate over the linguistic and minority rights. At the same time, the previously taboo topic of national status of Hungarian (and other) minorities and the nature of their relationship with the mother country, resurfaced as well. Hungarian interests across the political spectrum are clearly defined by a desire to improve connections between Motherland and Hungarian communities as well as improve the living standards and stabilise the conditions in neighbourhood areas as a means to keep Hungarians thriving there. To these ends, both EU and national regional development funding, including $\mathrm{CBC}$ instruments, have been employed, whereby 'Hungarian-Hungarian' relations have gradually achieved explicit priority in the use of EU resources. $^{3}$

The political intensity of 'ethnopolitical $\mathrm{CBC}^{\prime}$ has generally increased during national-conservative governments (1998-2002, 2010-present) which above and beyond economic issues, have raised questions of linguistic rights, regional autonomy and the nature of political relationships of ethnic Hungarians with the kin state. Indeed, members of Orbán's government, as well as the Prime Minister himself, have propagated the idea of effectively de-bordering the Carpathian Basin in order to create new (trans)national spaces for Hungarians. Whereas earlier versions of the Carpathian Basin narrative focused on creating a coherent economic and environmental space through cooperation (Horváth 2010), since 2010 the idea of a specific Hungarian

3 See Hungary's External Relations Strategy (2013: 10). Source: www.mfa.gov.hu/NR/rdonlyres/3E8FA37015B3.../080319_kulkapcs_strat_en.pd [13 May 2017]. mission to integrate the Carpathian Basin has gained considerable political traction. The Minister in Charge of the Prime Ministers' office, János Lázár, has, for example, openly declared in parliamentary debates the need to "preserve the hegemony of Hungary in the Carpathian Basin". ${ }^{4}$ In national-conservative readings therefore, a clear distinction is made between Hungary as a territorial state, reflected in the present day borders of the country, and Hungary as a nation, in which extra-territorial political agency is a legitimate form of promoting Hungarian minority interests. ${ }^{5}$

Hopes for greater dynamism in local and regional development through 'HungarianHungarian' network economies were shared by actors at all levels, but the highly political nature of re-connecting cities within the 'Carpathian Basin' was exemplified by the effective co-optation of $\mathrm{CBC}$ by the national government. As a result, CBC between Hungary and its neighbours has been subsequently and systematically politicised by all political parties, especially with increasing ideological polarisation of the political landscape in Hungary during the late 1990s and early 2000s. This was exacerbated by controversial programmes adopted during the first Orbán government, such as the 2001 Status Law which provided special privileges, including services and quasi-residency rights in Hungary, to ethnic Hungarian living in neighbouring states. The emphasis on ethnic relations within the 'Carpathian Basin' has been met with considerable mistrust and apprehension by Hungary's neighbours who at times have interpreted

\footnotetext{
${ }^{4}$ As reported during a debate of 24 February 2016. Source: http://index.hu/belfold/2016/02/24/ lazar_schiffer_vona_Imp_josz_terrorizmus_oroszorszag_europa/ [12 May 2017].

${ }^{5}$ As frequently expressed by Minister Zoltán Balog who professes an 'integrated' approach to the social, cultural and economic development of the Carpathian Basin. This was reiterated in a speech given in Romania, at the Tusványos Summer Free University on 20 July 2017 and reported in the official FIDESZ party website: egységes Kárpát-medencei térben kell gondolkodni (we need to think in terms of a unified Carpathian Basin space), http://www.fidesz.hu/hirek/2017-07-20/balogegyseges-karpat-medencei-terben-kell-gondolkodni/ [20 July 2017].
} 
$\mathrm{CBC}$ as a means to extend Hungarian extraterritorial sovereignty claims (Arraiza 2015). They also elicited strong reactions from the European Union as well

Border ethnopolitics have also strengthened the trend towards centralisation under Viktor Orbáns government, in power since 2010. Support for regionalisation and greater local agency in CBC was initially provided after 1996, but the role of Euroregions and special agencies dedicated to $C B C$ diminished rapidly after 2010 (Medve-Bálint 2013). While regional level cooperation in the form of EGTCs (European Groupings for Territorial Cooperation) has emerged at Hungary's borders, a decisive role is maintained by the central government in Budapest. Furthermore, cross-border institutions such as the Permanent Conference of Hungarians or MÁÉRT(in Hungarian: Magyar Állandó Értekezletet), created under Orbáns first government and that target direct political cooperation between Budapest and representatives of ethnic Hungarians have now a much more prominent role. These institutions have contribute to the politicisation of $\mathrm{CBC}$ by subsuming local and regional cooperation within the larger nation-building agenda of the national-conservative government.

\section{Border politics and securitisation policies}

Most recently, CBC in Central Europe has been directly impacted by the events since 2015 in which border security has been tightened in response to the dramatic increase in asylum-seekers and migrants. By the writing of this article in 2017 border controls between several CECs had been reinstated, much to the chagrin of cross-border commuters and local communities at the borders. The securitisation of borders in Central Europe is also a question of state sovereignty and its enhancement, particularly in the case of Hungary. With the advent and consolidation of national conservative government in 2010, Hungary's border politics have become increasingly confrontational, contesting the European Union attempts to find a community-wide approach to deal with the needs of refugees and migrants. ${ }^{6}$

In addition, Orbán's government has exploited borders, physically and symbolically in ways that resonate with popular fear of migrants and conservative skepticism of multiculturalism and open borders. This is clearly manifested in Hungary's border policies of 2015/2016 which, in response to and in exploitation of the refugee 'crisis', have seen new border fortifications, a partial militarisation of border areas and a direct challenge to the Schengen Agreements. With the installation and reinforcement of barbed wire fences and internment camps along its border with Serbia and Croatia, Hungary's mobility control practices have since 2015 achieved a new intensity. Commenting on his government's 'zero refugees strategy', Hungarian Prime Minister Viktor Orbán argued in 2015 the inviolability of national sovereignty over borders:

"(...) the basics are that each nation is defined by its borders. Borders must be respected. And borders must be defended by the state. [...] And if you are a member of the European Union, especially the Schengen Area, you have an obligation to defend your national border, which is the European border, to stop them. Everybody who would like to cross the border in an illegal way: stop them and defend the border to defend your community and to defend Europe."

Hungarian Foreign Minister Szijjártó has argued that German Chancellor Merkel's welcome culture has in fact been self-serving, opening up Germany at the expense of smaller member states through which refugees and migrant transit.? Hungary's open animosity

\footnotetext{
6 This is evidenced by widespread media coverage since 2015 of Hungary's refusal to accept refugees according to EU rules. See the Politico article 'Hungary's zero refugee strategy', available at: http://www.politico. $\mathrm{eu/article/hungary-zero-refugee-strategy-viktor-orban-}$ europe-migration-crisis/ [15 February 2017].

7 Handelsblatt Global of 6 April 2016 reports: "Hungarian Minister: We Were Right to Build Fences. Hungarian Foreign Minister Péter Szijjártó justifies
} 
towards the welcome culture idea is of course shared by many political groupings within the EU. The basis for the antagonism is the fear of socio-ethnic and religious tensions as well as increased social costs of caring for refugees. On the other hand, crime, terrorism and insecurity are openly associated not only with refugees but also illegal migrants (Fekete 2016).

The Hungarian government's securitisation of mobility has culminated in the creation of four 'transit zones' on the border with Serbia and Croatia in order to 'fix', as it were, asylum-seekers in time and space and make them invisible to mainstream society. Since 2016, applications for asylum can only be processed at the border camps, anyone apprehended crossing the Hungary's borders at other points will be sent immediately back to Serbia. The immobilisation of refugee flows is both a deterrent as well as a clear expression of the government's resolve to reject any EU-level quotas or regulations that impinge upon national sovereignty. This policy is seen by critics as tantamount to imprisonment and a blatant violation of human rights. ${ }^{8}$

Hungary's border securitisation practices are not only (geo)political but also cultural in nature. Borders are used to position Hungary as a major player in its quest to promote traditional values and as a defender of national sovereignty and identity (Butler 2017). ${ }^{9}$ Hungary portrays itself not as a follower, but

his country's decision to build razor wire fences on its borders and warns that Europe's refugee crisis is likely to become a permanent state of affairs". Available at https://global.handelsblatt.com/politics/hungarianminister-we-were-right-to-build-fences-487839 March 2017].

8 The Hungarian Spectrum of 14 June 2017 reports that "Hungary's transit zones are actually prisons where even pregnant women are handcuffed", http:// hungarianspectrum.org/2017/06/14/hungarys-transitzones-are-actually-prisons-where-even-pregnant-women-are-handcuffed/ [24 June 2017].

9 See the blog posted on 6 November 2016 by MIGSZOL, the Migrant Solidarity Group of Hungary, entitled Protecting Hungary's "national identity"? - Orban's constitutional amendments and EU law, available at: http://www.migszol.com/blog/protecting-hungarysnational-identity-orbans-constitutional-amendmentsand-eu-law (31 March 2017). as an innovator and maker of Europe, according to notions of 'national Europe' and against the 'political correctness' of Brussels bureaucrats and other major politicians (Szarka 2017). Furthermore, in legitimizing border closures and with a dismissive approach to Europe's refugee crisis, the present Hungarian government under Viktor Orbán has stylised itself as a guardian of Europe's historical legacy and Christian culture..$^{10}$ It has warned constantly of the dangers of 'unnatural migration' and the emergence of parallel (Islamic) societies that will threaten Europe's welfare, security and identity. ${ }^{11}$ This discourse is supported by constant negative Hungarian media coverage of Europe's refugee crisis and conspiracy theories that suggest an 'externally' driven exploitation of Europe's open societies. Pointedly, in mobilising support for fences, Hungary's prime minister suggests that 'illiberal' values are needed in order to protect national societies and guard against naive notions of openness and tolerance (Zalan 2016).

\section{Conclusions: On the salience of border politics}

What does the evidence provided above signify in terms of re-bordering Central Europe? The case of Hungary, while singular in many ways, reminds us that the geopolitics of borders permeates many levels of political life despite the momentum and de-bordering impact

\footnotetext{
10 See the Guardian article of 3 September 2015: Migration crisis: Hungary PM says Europe in grip of madness, available at: https://www.theguardian. com/world/2015/sep/03/migration-crisis-hungary-pmvictor-orban-europe-response-madness (31 February 2017). Similarly, he Guardian of 26 July 2016 reports that 'Hungarian prime minister says migrants are 'poison' and 'not needed", available at: https://www. theguardian.com/world/2016/jul/26/hungarian-primeminister-viktor-orban-praises-donald-trump (23 March 2017).

11 Reported, for example, in the Sunday Express of 27 September 2016, with dramatic headlines: 'You're DESTROYING Europe' Hungary PM predicts 'parallel Muslim society' due to migration, available at: http:/ www.express.co.uk/news/world/715040/Hungaryreferendum-Viktor-Orban-parallel-Muslim-societies-EUmigration-refugees (21 March 2017).
} 
of European integration. Gabriel Popescu (2011) has argued that the normative political language of Europeanisation (e.g. as a process of integrating territorial development across national borders) often contrasts with local realities where cross-border co-operation $(\mathrm{CBC})$ reflects competing territorial logics and conflicting attitudes towards more open borders. More than two decades after the end of the Cold War, borders themselves are both resources for but in many circumstances often obstacles to greater political and social interaction, even if the defensive character of European borders has virtually disappeared.

One of the reasons for this state of affairs is the ongoing process of re-positioning which Central European countries are engaged in and, consequently, the instrumental role that borders assume in political, social and economic terms. Repositioning refers specifically to finding a national role within Europe - a project that is inherently contested and which in the case of CECs has been a source of 'East-West' conflict. East-West difference is not about deep civilisation divides but reflects historically contingent processes of national becoming, evidenced here by the socio-political and cultural nature of CEC border politics; this includes a focus on national consolidation that has also tended to de-emphasise local forms of co-operation more generally in Central Europe.

In the case of Hungary, CBC is certainly understood in terms of European Cohesion but is heavily influenced by overlying political goals of nation-building and improving the living conditions of ethnic Hungarian communities in neighbouring states. However, the inherently extraterritorial nature of Hungary's border politics is itself problematic in terms of improved neighbourhood relations as it promotes interpretations of $\mathrm{CBC}$ as a means to extend Hungarian political influences and, in worst case scenarios, extraterritorial sovereignty claims. Furthermore, Hungary's border politics are presently dominated by national conservative and Eurosceptic thinking which has produced a degree of ethnopolitical and nationalist extremism.
This extreme form of border politics is most likely unsustainable precisely because it will alienate many potential cooperation partners both domestically and across borders. If the Hungarian government's avowed aim is the flourishing of all Hungarian communities in the Carpathian Basin then there will no alternative to multilateral dialogue, trustbuilding, local-level empowerment and the de-politicisation of CBC. A sensitive border politics would reflect the longue durée nature of creating cross-border political practices at the local and regional level. Furthermore, local and regional actors would be encouraged to develop cooperation mechanisms situationally and in ways that respond to political opportunities and social and structural conditions. By the same token, one means to counteract the marginalisation of cross-border cooperation and insensitivity to specific regional situations at and around Hungary's borders could very well be the recognition of regional autonomies that respect national sovereignties but provide rights linguistically, culturally and in terms of self-government. Local autonomies based on a transsovereign model (see Bakk \& Öllös 2010) could be a major potential means of empowering local CBC but also for improving prospects for more general economic and social integration within Central and Eastern Europe. However the basis for such a model can only be a greater degree of trust and mutual goodwill. 


\section{References}

ArraizA J.-M., 2015. Good neighbourliness as a limit to extraterritorial citizenship: The case of Hungary and Slovakia [in:] D. Kochenov, E. Basheska (eds.), Good neighbourly relations in the European legal context, Amsterdam: Brill Nijhoff, pp. 114-135.

BAKK M., ÖLlös L. 2010. Politikai közösség és kulturális identitás Magyarország és a szomsédos országok magyar kisebbségeinek viszonyban [in:] B. Bitskey (ed.), Határon túli magyarság a 21 szazadban, Budapest: Koztársasági Elnöki Hivatal, pp. 41-68.

Balogh P., 2014. Perpetual borders: German-Polish cross-border contacts in the Szczecin Area. Stockholm: Stockholm University.

BARANYI B., 2001. A periféria perifériájá - egy kérdőives vizsgálat eredményei és tanulságai az Északkelet-Alföldi határ menti területein [in:] B. Baranyi (ed.) A Határmentiség kérdőjelei az Északkelet-Alföldön, Pécs: MTA Regionális Kutatások Központja, pp. 55-86.

BARANYI B., 2008. Magyar-ukrán határrégió: Magyar-ukrán határrégió. Debrecen: MTA Regionális Kutatások Központja.

BARTA G., 2006. Hungary - the new border of the European Union. Discussion Papers of the Centre for Regional Studies, no. 54, Pécs: Centre for Regional Studies of the Hungarian Academy of Sciences.

Batory A., 2010. Kin-state identity in the European context: Citizenship, nationalism and constitutionalism in Hungary. Nations and Nationalism, vol. 16, no. 1, pp. 31-48.

BIHARI Z., Kovács K., 2005. Slopes and slides: Spatial inequalities in employment opportunities at the turn of the millennium [in:] G. Barta, É.G. Fekete, I. Kukorelli Szörényiné, J. Timár (eds.), Hungarian spaces and places: Patterns of transition, Pécs: Centre for Regional Studies, pp. 360-378.

BLATTER J., 2001. Debordering the world of states: Toward a multi-level system in Europe and a multi-polity system in North America? Insights from border regions. European Journal of International Relations, vol. 7, no. 2, pp. 175-209.

BöHM H., 2015. Czech-Polish borders: Comparison of the EU funds for cross-border co-operation of schools in selected Euroregions. Cross-Border Review Yearbook 2015, pp. 59-74, http://institute. cesci-net.eu/en/crossborder-review-2015 [01 April 2016].

BOJAR E., 2008. Euroregions in Poland. Tijdschrift voor Economische en Sociale Geografie, vol. 87, no. 5, pp. 442-447.

BoldizSAR I., 1988. In a good cause. New Hungarian Quarterly, vol. 29, no. 111, pp. 52-56.

BRUBAKER R., 1996. Nationalism reframed. nationhood and the national question in the new Europe. Cambridge: Cambridge University Press.

BRUSIS M., 2005. The instrumental use of European Union conditionality: Regionalization in the Czech Republic and Slovakia. East European Politics \& Societies, vol. 19, no. 2, pp. 291-316,

Bufon M., Markeu V., 2010. Regional policies and cross-border cooperation: New challenges and new development models in Central Europe. Revista Romana de Geografia Politica, year XII, no. 1. pp. 18-28.

DE SOUSA L., 2013. Understanding European crossborder cooperation: A framework for analysis. Journal of European Integration, vol. 35, no. 6, pp. 669-687.

DotzBtasz S., 2013. Cross-border co-operation in the Euroregions at the Polish-Czech and Polish-Slovak borders. European Countryside, vol. 5, no. 2, pp. 102-114.

DołzBŁAsz S., 2015. Symmetry or asymmetry? Cross-border openness of service providers in Polish-Czech and Polish-German border towns. Moravian Geographical Reports, vol. 23, no. 1, pp. 2-12.

Domaniewski S., StudzIŃSKa D., 2016. The small border traffic zone between Poland and Kaliningrad Region (Russia): The impact of a local visafree border regime. Geopolitics, vol. 21, no. 3, pp. 538-555.

EGER G., 2000. Regionalism, the Euroregion as the specific spatial form of integration, Budapest: Osiris.

Gorzelak G., SmętKowski M., 2007. Regional dynamics in Central and Eastern Europe. Paper presented at the International Conference "Regional Development in Central and Easter Europe", 20-22 September 2007, University of Warsaw, Poland.

Gorzelak G., SmętKowski M., 2010. Regional development dynamics in Central and Eastern European countries [in:] G. Gorzelak, J. Bachtler, M. Smetkowski (eds.), Regional development 
in Central and Eastern Europe, London, New York: Routledge, pp. 34-58.

HAudú Z., 1995. A magyar államtér változásainak történeti és politikai földrajzi szemlélete a magyar földrajztudományban 1948-ig. Tér és Társadalom, vol. 9, no. 3-4, pp. 111-132.

HAJDú Z., 1998. Changes in the politico-geographical position of Hungary in the 20th century. Discussion Papers, no. 22, Pécs: Centre for Regional Studies.

HAJDÚ Z., 2008. Kárpát-medence államosodási folyamatainak változásai és történeti földrajzi elemzésük. Korall, 31, pp. 75-100.

Hajdú Z., Lux G., Kovács Pálné I., Somolyódné Pfeil E., 2009. Local dimensions of a wider European neighbourhood: Cross-border relations and civil society in the Hungarian-Ukrainian border area. Discussion Papers, no. 71, Pécs: Centre for Regional Studies.

Hakszer R., 2017. A 2007-2013-as Magyarország-Szlovákia Határon Átnyúló Együttmüködési Program regionális aspektusai, megválositásának tapasztalatai. Tér és Társadalom, vol. 31, no. 1, pp. 107-123.

HARDI T., 2003. Az EU-csatlakozás hatása a határ menti térségek fejlődésére a Nyugat-Dunántúlon [in:] M. Kis, L. Gulyás, E. Erdélyi (eds.), Európai kihívások 2. Tudományos konferencia, Szeged: Szegedi Tudományegyetem Szegedi Élelmiszeripari Főiskolai Kar, pp, 158-162.

HARDI T., 2010. Határ menti térségek, határon átnyúló kapcsolatok [in:] V. Szirmai (ed.), Közép-Dunántúl, Pécs-Budapest: MTA Regionális Kutatások Központja - Dialóg Campus Kiadó.

HerRSChel T., 2011. Borders in post-socialist Europe: Territory, scale, society. Farnham, Burlington: Ashgate.

HoRváth G. 2010. Territorial cohesion in the Carpathian Basin: Trends and tasks. Discussion Papers, no. 81, Pécs: Centre for Regional Studies.

JACOBS J., VARRÓ K., 2014. Rethinking cross-border Euregionalism as a self-organising system. Space and Polity, vol. 18, no. 1, pp.1-16.

JAŃCZAK J., 2013. Revised boundaries and re-frontierization. Border twin towns in Central Europe. Revue d'études comparatives Est-Ouest, vol. 44, no. 4, pp. 53-92.

JAŃCZAK J., 2014. Border twin towns in Europe: Cross-border cooperation at a local level. Berlin: LogosVerlag.
JESSOP B., 2002. The political economy of scale and the construction of cross-border micro-regions [in:] F. Söderbaum, T. Shaw (eds), Theories of New Regionalism, pp. 179-196.

KEMÉNYFI R., 2006. Az "ezeréves határok" etnikai területek legitimaciós eszközei a 20. század elsó felének földrajzban [in:] B. Bakó, R. Papp, L. Szarka (eds.), Mindennapi elő́téletek. Társadalmi távolságok és etnikai sztereotípiák, Budapest: Balassi Kiádó, pp. 325-344.

KozAK M., 2014. Subregion Jelenia Góra as an example of border region - Case study report. GRINCOH Working Paper Series, Paper No. 6.03.02.01, http://www.grincoh.eu/ media/serie_6_spaces_territories_and_ regions/grincoh_wp6.03.02.01_kozak.pdf [23 May 2017].

Kukorelli I., Dancs L., Hajdú Z., Kugler J., NAGY I., 2000. Hungary's seven border regions. Journal of Borderlands Studies, vol. 15, no. 1, pp. 221-254.

LADOS M., 2005. A határmentiségtól az integrált határrégióig. Tér és Társadalom, vol. 19, no. 2, pp, 1-5.

Leibenath M., Korcelli-Olejniczak E., KnippsCHILD R. (eds.), 2008. Cross-border Governance and Sustainable Spatial Development. Berlin: Springer

LEPIK K., 2012. Cross-border cooperation institutional organization. Saarbrücken: Lampert Publishing.

LEPIK K., 2009. Euroregions as mechanisms for strengthening of cross-border cooperation in the Baltic Sea region. TRAMES, vol. 13, no. 3, pp. 265-284.

Lux G. (ed.), 2010. Environmental policy and the institutional system of environmental protection in the Carpathian Basin. Discussion Papers, no. 79, Environmental Policy and the Institutional System of Environment Protection in the Carpathian Basin, Pécs: Centre for Regional Studies of the Hungarian Academy of Sciences.

Medve-Bálint G., 2013. Incentives and obstacles to cross-border cooperation in post-communist Central Europe [in:] N. Bellini, U. Hilpert (eds.), Europe's changing geography: The impact of inter-regional networks, London-New York: Routledge, pp. 145-170.

Medve-Bálint G., SVensson S., 2013. Diversity and development: Policy entrepreneurship of Euroregional initiatives in Central and Eastern Europe. 
Journal of Borderlands Studies, vol. 28, no. 1, pp. 15-31.

Mezel I., 2008. Városok Szlovákiában és a magyar határ mentén. Somorja-Pécs: MTA Regionális Kutatások Központja, Fórum Kisebbségkutató Intézet.

MønNeSLAND J., 1999. Cross border programmes versus regional development programmes. The population density influence. Paper presented at the Regional Studies Association Conference, 21-24 September, Bilbao, Spain.

NAGY G. 2011. Gyula - város a határon. A központi funkciók határon átnyúló hatása. Tér és Tarsadalom, vol. 25, no. 4, pp. 127-147.

National Development Agency, 2007. New Hungary Development Plan. National Strategic Reference Framework 2007-2013. Budapest: NDA

Newman D., 2011. Contemporary research agendas in border studies: An overview [in:] D. WastlWalter (ed.), The Ashgate research companion to border studies. Farnham: Ashgate, pp. 33-47.

NAGY G., 2011. Gyula - város a határon. A központi funkciók határon átnyúló hatása. Tér és Tarsadalom, vol. 25, no. 4, pp. 127-147.

NAGY E., NAGY G., 2013. The layers of dependence and the changing role of the state - Conceptualising urban change in the East of Europe [in:] RC21 Conference - Resourceful cities. Konferencia helye, ideje: Berlin, Németország, 2013.08.292013.08.30. Berlin: Humboldt-Universität, Institute for Social Science, Department of Social Sciences Urban http://www.rc21.org/conferences/ berlin2013/RC21-Berlin-Papers-3/03_2_enagy_ gnagy.pdf. [15 October 2015].

O'DowD L., 2002. The changing significance of European borders. Regional and Federal Studies, vol. 12, no. 4), pp. 13-36.

O'DowD L., 2010. From a 'borderless world' to a 'world of borders': Bringing history back in. Environment and Planning D: Society and Space, vol. 28, no. 6, pp. 1031-1050.

ORLOWSKI W., 2010. The puzzles of convergence [in:] G. Gorzelak, J. Bachtler, M. Smętkowski (eds.), Regional Development in Central and Eastern Europe: Development processes and policy challenges, London-New York: Routledge, pp. 7-18.

PAASI A., 2012. Border studies reanimated: Going beyond the territorial/relational divide. Environment and Planning A, vol. 44, pp. 2303-2309.
PAASI A., 2013. 2007-2013 Hungarian multilevel governance. With or without regions? [in:] I. Pálné Kovács, J W. Scott, Z. Gál (eds.), Territorial Cohesion in Europe, Budapest: Institute for Regional Studies Centre for Economic and Regional Studies, pp. 455-466.

Perkmann M., 2007. Policy entrepreneurship and multilevel governance: A comparative study of European cross-border regions. Environment and Planning C, vol. 25, no. 6, pp. 861-879.

Perkmann M., 2002. The rise of the Euroregion. A bird's eye perspective on European crossborder co-operation. Department of Sociology at Lancaster University http://www.lancaster. ac.uk/fass/resources/sociology-online-papers/ papers/perkmann-rise-of-euroregion.pdf [15 August 2017]

PICKLES J., 2010. The spirit of post-socialism: Common spaces and the production of diversity. European Urban and Regional Studies, vol. 17, no. 2, p. 127-40.

POPESCU G., 2008. The conflicting logics of crossborder reterritorialization: Geopolitics of Euroregions in Eastern Europe. Political Geography, vol. 27, no. 4, pp.418-438.

POPESCU G., 2006. Geopolitics of scale and crossborder cooperation in Eastern Europe: The case of the Romanian-Ukrainian-Moldovan borderlands [in:] J. Scott (ed.), EU enlargement, region building and shifting borders of inclusion and exclusion, Aldershot: Ashgate, pp. 35-51.

POPESCU G., 2011. Bordering and ordering the twenty-first century: Understanding borders. Lathham (MD): Rowman and Littlefield.

RÁcz S. (ed.), 2006. Regionális átalakulás a Kárpát medencében. Pécs: MTA Magyar Regionális Tudományi Társáság.

RECHNITZER J., 2001. Border regions and national strategy. Györ, Pécs: Centre for Regional Studies.

RECHNitzer J. (ed.), 1990. A nyitott határ. Győr: MTA Regionális Kutatások Központja

Sarmiento-Mirwaldt K., Roman-Kamphaus U., 2013. Crossborder cooperation in Central Europe: A comparison of culture and policy effectiveness in the Polish-German and Polish-Slovak border regions. Europe-Asia Studies, vol. 65, no. 8 , pp. 1621-1641

Scom J.W., 2012. European politics of borders, border symbolism and cross-border cooperation [in:] T. Wilson, H. Donnan (eds.), A Companion 
to Border Studies, Hoboken: Wiley-Blackwell, pp 83-99.

Scot J.W., Szalal B., 2014. Case study report: Central Hungarian Region and Budapest Agglomeration. Working Paper Series, GRINCOH, Paper No. 6.06.01. http://www.grincoh.eu/media/serie_6_spaces_territories_and_regions/ grincoh_wp6.06.01_scott_szalai.pdf [23 May 2017].

SoHn C., 2014. The border as a resource in the global urban space: A contribution to the crossborder metropolis hypothesis. International Journal of Urban and Regional Research, vol. 38, no. 5, pp. 1697-1711.

Soós E., 2014. Endeavours to establish EGCTs on Hungary's external borders [in:] L. Domínguez, I. Pires (eds.), Cross-border cooperation structures in Europe: Learning from the past, looking to the future, Brussels: P.I.E: Lang, pp, 213-227.

Soós E., Fejes, Z., 2008. Hungarian experiences of cross-border cooperation. Fundamentum, no. 5, pp. 123-157.

Soós E., FEJES, Z., 2007. The institutionalisation of cross-border cooperation systems in Hungary. Európai Tükör (June), pp. 104-121.

SülI-ZAKAR I., (ed.), 2002. Borders and cross-border co-operations in the Central European transformation countries: Papers presented at the international workshop, Debrecen (Hungary) 1-2 October 2001. Debrecen: Kossuth Egyetemi K.

Süli-Zakar I., CZIMre K., (eds.) 2001. Carpathian Euroregion: Borders in the region, cross-border cooperation: European Study Centre Programme of the University of Debrecen: International workshop: Debrecen, Hungary, Oradea, Salonta, Romania, 16-17 December 1999. Debrecen: Kossuth Egy. K.

SVENSSON S., 2015. The bordered world of crossborder cooperation: The determinants of local government contact networks within Euroregions. Regional \& Federal Studies, vol. 25, no. 3, pp. 277-295,

Svensson S., Medve-Bálint G., 2012. Explaining coverage: Why local governments in Central Europe do or do not join Euroregions? [in:] D.J. Andersen, M. Klatt, M. Sandberg (eds.), The border multiple: The practicing of borders between public policy and everyday life in a re-scaling Europe, Furnham: Ashgate, pp. 219-245.

Van Houtum H., Van Naerssen T., 2002. Bordering, ordering and othering. Tijdschrift voor Economische en Sociale Geografie, vol. 93, no. 2, pp. 125-136.

VARRÓ K., 2008. Changing narratives on EU multi-level space in a globalizing era: How Hungary as a national space became part of the story. European Planning Studies, vol. 16, no. 7, pp. 955- 969. 